\title{
Beetroot and radish root yield in organic double-cropping production system
}

\author{
Milan Ugrinovićí ${ }^{*}$ - Bogoljub Zečević ${ }^{1}$ Zdenka Girek ${ }^{1}$ Suzana Pavlović ${ }^{\prime}$ Ivan Krga' · Jelena \\ Damnjanović ${ }^{1}$ Milka Brdar Jokanović ${ }^{2}$
}

${ }^{1}$ Institute for Vegetable Crops, Karađordeva 71, 11420 Smederevska Palanka, Serbia

Institute of Field and Vegetable Crops, Maksima Gorkog 30,21000 Novi Sad, Serbia

\begin{abstract}
Summary: Despite numerous positive effects on the environment, increased demands, intense research, and adequate public attention, crops grown according to the principles of organic production still occupy considerably small areas. It is difficult for certified producers to decide to expand the production of certified organic vegetables. One of the reasons is the insufficiently developed growing technology of different vegetable species in accordance with the law and regulations on organic production. Intercropping, growing of subsequent crops, and application of microbiological fertilizers are considered as the most useful techniques for yield increases in sustainable growing practices. The aim of this study was to investigate the possibilities for enhancing root yield of beetroot and radish, when grown as second crops in an organic double-cropping production system. The effects of intercropping and applying microbial fertilizers on the vegetable root weights were assessed. Intercropping was with green beans, implemented by replacement series method. Two microbial fertilizers were applied, one containing selected strains of Bacillus megaterium, B. licheniformis, B. suptilis, Azotobacter cbrocoocum, A. vinelandi and Derxia sp. (M1), and other with Bacillus subtilis, Asotobacter sp., Penicillium oxalicum and Fusarim sp. (M2). Intercropping and microbial fertilizers contributed to the root weight increase. The highest root weights were noted for the intercropped plants treated with M1 (beetroot, $151.8 \mathrm{~g}$ ) and M2 (radish, $351.0 \mathrm{~g}$ ), which was $23.5 \%$ and $15.5 \%$ higher than in the sole crop unfertilized control. The results imply combining intercropping and the appropriate microbial fertilizers as an effective strategy for increasing yields of organically grown beetroot and radish.
\end{abstract}

Key words: Beta mulgaris L. var. mbra, organic farming, intercropping, microbial fertilizers, Raphamus sativus $\mathrm{L}$.

\section{Introduction}

As an environmentally sound method, organic plant production improves soil structure and microbial activity, enhances water quality, promotes biodiversity, and reduces human and animal exposure to potentially harmful pesticides and other chemicals. Unlike in conventional intensive production systems implying the application of synthetic mineral fertilizers, the adequate nutrition of the plants grown in the organic system

Corresponding author

milan.ugrinovic@gmail.com

Acknowledgements:

This research is part of the project "New concept of breeding vegetable varieties and hybrids for sustainable growing systems using biotechnological methods (TR-31059, 2011-2019)", supported by the Ministry of Education, Science and Technological Development of the Republic of Setbia.

Cite this article:

Ugrinović M., Zečević B., Girek Z., Pavlović S., Krga I., Damnjanović J., Brdar Jokanović M. (2020). Beetroot and radish toot yield in organic double-cropping production system. Ratar. Pornt, 57 (3), 93-98.

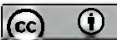

Copyright $($ The Author's) 2020 should be achieved primarily through the soil fertility improvement. This is carried out with different livestock manures and various composted materials, i.e. mixtures of compost as well as raw materials of natural origin, which are not derived from synthetic chemical processes (Lee et al., 2015; van Bruggen et al., 2016; Lorenz and Lal, 2016; Garibaldi et al., 2017; Hu et al., 2018; IFOAM, 2019).

Since the presence of macro- and microelements in the soil does not necessarily mean their immediate accessibility to plants, the fertilizers containing different strains of microorganisms that are non-pathogenic for plants, are becoming increasingly important. Plant growth promoters, such as beneficial strains of some bacterial species (Azotobacter sp, Derxia sp., Bacillus sp., Rhizobium leguminosarum etc.), contribute to the plant growth and reduce the need for additional fertilization, which refers to both organic and conventional production (Hayat et al., 2010; Sripontan et al., 2014; Ugrinovic et al. 2014; Miskoska - Milevska et al. 2018).

Soil microorganisms are involved in numerous biochemical processes. The most important are those 
related to organic matter decomposition and mineralization, and transformation of the elements from complex compounds into soluble forms that are available to plants. The strains of various microorganisms collected from the natural habitats and tested in laboratory and field trials are the most commonly used starting material for the production of microbial fertilizers. There are microorganisms that inhabit some plant species creating mutual symbiotic relationships. Owing to the symbiosis with endophytic bacteria located in the root nodules the species of the legume family (Fabaceal) indirectly use air nitrogen, which makes them the very good preceding crops. Including legumes into intercropping combinations may optimize plant nutrition simultaneously increasing crop biodiversity; therefore, the system may be beneficial for the productivity of the cultivated vegetables. Despite the intensive research, there are still unresolved issues, which are for the most part due to the complex plantmicroorganism interactions, applied microorganisms suppression by autochthonous soil and other environmental microorganisms, insufficiently developed application design, untimely exposure to precipitation and other environmental factors, etc. Thus, the efficiency of the microbial fertilizers in different agricultural plants has not been sufficiently explored and there are still plant species with the unpredictable response to the applied treatments (Betencourt et al., 2012; Dinić et al., 2014; Ugrinovic et al., 2014; Stamenković et al., 2018).

However, despite numerous positive effects on the environment, cultivated area increase, intense research and adequate public awareness, crops grown according to the principles of organic production still occupy considerably small areas; e.g. in the European Union up to $7 \%$ of the total utilized agricultural land. In addition to the demanding conversion from conventional to organic production which in most cases implies changes and adjustments in previously well-established agronomic procedures, bureaucratic costs and need for constant education; lower (20\%, on average) and less stable yields contribute to the small share of organically maintained crops. Making the production economically feasible is therefore the main prerequisite for its expansion; and necessitates the research on yield stabilization which implies plant species and varieties, cropping systems, as well as agronomic procedures types, methods and times of application (de Ponti et al., 2012; EUROSTAT, 2019; Kawasaki, 2019).

Double-cropping is the practice that involves consecutive growing and harvesting two (same or different) crops in the same field during the same season. Besides obvious profit-related benefits, the practice has been associated with improvements in soil fertility and with soil erosion prevention. Having in mind the possible yield gap between conventional and organic agriculture, double-cropping could contribute to balance between costs and profit in organic agriculture.
It has been proposed as a candidate strategy for yield improvements in areas with temperature sum sufficient for completing the life cycles of two crops, as well as in the regions that are expected to change climate in terms of the temperature increase, such as Balkan Peninsula (Dubrovsky et al. 2013).

As a general rule, the subsequent crop should be of shorter life cycle and it is expected to have lower yield comparing to the timely grown crop of the same variety. Therefore, it should be carefully chosen to successfully fit into the production system existing in a particular region. Beetroot and radish have been investigated in this study because the vegetables have been recommended for growing in organic production and have short vegetation (Maroušek et al., 2017; Carlos et al., 2018; Chhikara, 2019).

The purpose of this study was to investigate the possibilities to improve yield in beetroot and radish grown as second crops in an organic double-cropping production system, by means of intercropping with green beans and applying two different microbial fertilizers.

\section{Material and Methods}

The trial was set up at an organically managed experimental field of the Institute for Vegetable Crops, Smederevska Palanka, Serbia (102 m altitude, 4422' north latitude, 20047 east longitude), within a comprehensive four-year experiment (2009-2012) including multiple vegetable species, organic fertilizers, sowing dates, cropping practices, as well as crop rotations. There were 36 elementary plots, distributed over a completely random block system (in three repetitions), with size of $2.5 \times 5.0 \mathrm{~m}$ each and surface area of $12.5 \mathrm{~m}^{2}$. The distance between the plots was $0.5 \mathrm{~m}$. The soil type was alluvial vertisol of good chemical properties, except for the absence of calcium carbonate (Tab. 1). Weather data collected from nearby meteorological station were retrieved from the official site of the Republic Hydrometeorological Service of Serbia (2019) and showed in Table 2. The values of the temperature parameters were slightly higher than the longterm averages. The occasional precipitation deficit was compensated by irrigation.

In accordance to the Law on Organic Production and the accompanying regulations, the species and varieties adapted to local agro-ecological conditions and/or selected and registered to the National List of Certified Plant Varieties of the Republic of Serbia (MAFWM, 2010; 2011; 2019) were chosen for the study. Beetroot (Beta vulgaris L. var. nubra, variety 'Palanackea red') and radish (Raphanus sativus L., variety 'Winter white') were grown as single crops and intercropped with green beans (Phaseolus vulgaris L. var. nanus, variety 'Sumadinkd). The intercropping was implemented according to the replacement series method (Vandermeer, 1989), where the green beans replaces every third and fourth row of the main crop. 
Table 1. Soil chemical properties at the experimental field

\begin{tabular}{llllll}
\hline $\mathrm{pH}(\mathrm{KCl})$ & $\mathrm{CaCO}_{3}(\%)$ & Humus $(\%)$ & Total $\mathrm{N}(\%)$ & Available $\mathrm{P}(\mathrm{ppm})$ & Available $\mathrm{K}(\mathrm{ppm})$ \\
\hline 6.75 & 0.0 & 2.9 & 0.13 & 234.2 & 235.6 \\
\hline
\end{tabular}

Table 2. Temperature and precipitation parameters for beetroot and radish (as subsequent crop, July - October) of 2009, 2010, 2011 and 2012, with long-term averages

\begin{tabular}{|c|c|c|c|c|c|c|}
\hline \multirow[b]{2}{*}{ Parameter } & \multicolumn{5}{|c|}{ Months } & \multirow[b]{2}{*}{ (VII-X } \\
\hline & Year & VII & VIII & $\mathrm{IX}$ & $\mathrm{X}$ & \\
\hline \multirow[t]{5}{*}{ Average monthly temperature $\left({ }^{\circ} \mathrm{C}\right)$} & 2009 & 22.4 & 22.7 & 18.7 & 11.9 & 18.9 \\
\hline & 2010 & 22.8 & 22.2 & 16.4 & 9.3 & 17.7 \\
\hline & 2011 & 23.0 & 23.2 & 20.5 & 10.2 & 19.2 \\
\hline & 2012 & 25.5 & 23.3 & 19.9 & 13.0 & 20.4 \\
\hline & $1981-2010$ & 22.0 & 21.6 & 16.8 & 11.7 & 18.0 \\
\hline \multirow[t]{5}{*}{ Sum of active temperatures $\left({ }^{\circ} \mathrm{C}\right)$} & 2009 & 694.4 & 703.7 & 561.0 & 368.9 & 2328.0 \\
\hline & 2010 & 706.8 & 688.2 & 492.0 & 288.3 & 2175.3 \\
\hline & 2011 & 713.0 & 719.2 & 615.0 & 316.2 & 2363.4 \\
\hline & 2012 & 790.5 & 722.3 & 597.0 & 403.0 & 2512.8 \\
\hline & $1981-2010$ & 682.0 & 669.6 & 504.0 & 362.7 & 2218.3 \\
\hline \multirow[t]{5}{*}{ Sum of precipitation $(\mathrm{mm})$} & 2009 & 103.6 & 8.9 & 13.5 & 105.3 & 231.3 \\
\hline & 2010 & 61.4 & 53.6 & 44.8 & 57.1 & 216.9 \\
\hline & 2011 & 54.5 & 8.0 & 32.1 & 26.9 & 121.5 \\
\hline & 2012 & 74.1 & 0.0 & 11.7 & 49.5 & 135.3 \\
\hline & $1981-2010$ & 60.5 & 58.9 & 56.4 & 51.2 & 227.0 \\
\hline
\end{tabular}

The two applied microbial fertilizers were made from mixtures of selected strains that are non-pathogenic for plants. The first (M1) contained Bacillus subtilis, Arotobacter sp., Penicillium oxalicum and Fusarium sp. (product commercial name: BioActive, manufactured by Vestal Chimica Italiana, s.r. Muggia, Italy), whereas the second (M2) included Bacillus megaterium, Bacillus licheniformis, Bacillus subtilis, Aqotobacter chrocoocum, Arotobatter vinelandi and Derxia sp. (Slavol, manufactured by Agrounik, Simanovci, Republic of Serbia). The trial included unfertilized control plots.

The preceding crop was winter barley. Agronomic procedures applied after its harvest included ploughing, disc harrowing and additional cultivation with rotary tiller. Sowing was done manually, in late July. After germination and seedlings appearance, thinning was performed to set the final spacing of $125 \times 10^{3}, 125 \times 10^{3}$ and $250 \times 10^{3}$ plants (beetroot, radish and green bean, respectively) per ha of sole crops. The trial was irrigated as needed, to maintain the field water capacity above $70 \%$. The microbial fertilizers were applied according to the instructions given by the manufacturers, at $0.5 \%$ (M1) and $1.5 \%$ (M2) concentration, when the green beans formed the first true leaves. The procedure was repeated after 10 days. Weeds were controlled manually.
The crops were harvested in early October. Twenty beetroot and radish plants per elementary plot were sampled for yield (i.e. root weight, g) analysis. Data was processed by analysis of variance and Duncan's test was used for comparisons of means.

\section{Results and discussion}

The analysis of variance revealed significant effect of cropping system on radish, and no effect on beetroot root weight, whereas microbial fertilizers significantly influenced root weights of both examined vegetables. On the other hand, the interaction of the cropping system and the applied fertilizers was not statistically significant (data not shown).

Sums of temperatures recorded during the growing period (Tab. 2) were favorable for achieving good yields in subsequently grown plants. The mean root weight per plant was $141.4 \mathrm{~g}$ measured for beetroot and 330.2 $\mathrm{g}$ for radish (Tabs. 3 and 4) which can be recalculated to approximately 17.7 and $41.3 \mathrm{tha}^{-1}$, respectively. The precipitation deficit which was particularly pronounced during the month of August was compensated by irrigation and therefore did not affect the crops. 
Table 3. Beetroot root weight (g), the effects of intercropping with green beans and applied microbial fertilizers

\begin{tabular}{|c|c|c|c|}
\hline \multirow{2}{*}{ Fertilizing treatment } & \multicolumn{2}{|c|}{ Cropping system } & \multirow{2}{*}{ Mean (fertilizing treatments) } \\
\hline & Sole crop ${ }^{* *}$ & Intercropping $^{* *}$ & \\
\hline Control $^{* *}$ & $122.9(5.8)$ & $127.1(5.6)$ & $125.0(5.4)^{a}$ \\
\hline $\mathrm{M} 1^{* *}$ & $149.8(6.5)$ & $151.8(5.9)$ & $150.8(5.9)^{\mathrm{b}}$ \\
\hline $\mathrm{M}^{2 *}$ & $148.7(7.1)$ & $148.2(8.9)$ & $148.5(7.5)^{b}$ \\
\hline Mean (cropping systems) ${ }^{*}$ & $140.5(7.9)^{\mathrm{A}}$ & $142.4(7.8)^{\mathrm{A}}$ & Grand mean: $141.4(7.7)$ \\
\hline
\end{tabular}

Table 4. Radish root weight (g), the effects of intercropping with green beans and applied microbial fertilizers

\begin{tabular}{llll}
\hline \multirow{2}{*}{ Fertilizing treatment } & \multicolumn{2}{l}{ Cropping system } & Mean (fertilizing treatments) \\
\cline { 2 - 4 } & Sole crop & Intercropping & \\
\hline Control $^{* *}$ & $303.8(9.3)$ & $312.6(12.1)$ & $308.2(10.0)^{\mathrm{a}}$ \\
M1 $^{* *}$ & $341.1(7.4)$ & $344.8(11.3)$ & $343.0(8.9)^{\mathrm{b}}$ \\
M2 $^{* *}$ & $328.1(9.6)$ & $351.0(9.1)$ & $339.6(11.4)^{\mathrm{b}}$ \\
\hline Mean (cropping systems) & $324.3(10.6)^{\mathrm{A}}$ & $336.1(14.2)^{\mathrm{B}}$ & Grand mean: $330.2(12.5)$ \\
\hline${ }^{*}$ - Means within the same column/row followed by the same letter do not differ significantly according to Duncan's test $(\mathrm{P}<0.05)$
\end{tabular}

The highest beetroot root weight was measured for the intercropped plants treated with M1 (151.8 g), and the lowest for sole crop unfertilized control plants $(122.9 \mathrm{~g})$. The roots of the intercropped plants treated with M2 weighted $148.2 \mathrm{~g}$, which was lower than M1, however below the threshold of statistical significance. The Duncan's test did not detect significant differences between the cropping systems in terms of beetroot root yield. In a similar experiment on timely-grown sole crop beetroot (Agic et al., 2018), the applied microbial fertilizers significantly contributed to the yield increase, however not to the same extent. In addition to beetroot, beneficial effects of different Arotobacter strains have been reported for other agricultural plants (Gosal et al., 2012; Zandi and Basu, 2016).

Concerning radish, the highest root weight was measured for intercropped plants treated with M2 $(351.0 \mathrm{~g})$. As expected, the lowest root weight had sole crop plants which were not treated with microbial fertilizer $(303.8 \mathrm{~g})$. Unlike for beetroot, intercropped radish yielded significantly better than as a sole crop. This confirmed the results of our previous research on intercropping other varieties of green beans and radish, where we found significantly lower intercrop efficiency in green beans, and higher in radish (Ugrinovic et al., 2014). The differences in intercrop efficiency imply radish as a strong competitor and dominant species in intercrop system which includes species from Fabaceae family. Intercropping radish with less competitive species alleviates the effects of strong intraspecific competition for water and nutrients, resulting in higher yield than in sole crops. Beneficial effects of intercropping radish with collard green (Pinheiro et al., 2019), cowpea (Nunes et al., 2018) and other agricultural plants (Yildirim and Guvenc, 2005; Sandler et al., 2015) have been reported.

\section{Conclusions}

On the basis of presented findings, good root yields in subsequently grown organic beetroot and radish are achievable. Intercropping beetroot with green beans according to the replacement series method did not increase beetroot root weight. On the other hand, intercropping radish with green beans decreased radish intraspecific competition for nutrients and water, which resulted in higher root weight.

Application of appropriate microbial fertilizers enhanced root weight in both sole crop and intercropped beetroot and radish, however the fertilizer efficiency varied among the crops.

Further research is required to synchronize plant species and variety, sowing time, microbial fertilizer type and cropping practice in order to maximize yield in vegetables grown according to the principles of organic agriculture. 


\section{References}

Agic, R., Zdravkovska, M., Popsimonova, G., Dimovska, D., Bogevska, Z., Davitkovska, M. (2018). Yield and quality of beetroot (Beta mulgaris ssp. esculenta L.) as a result of microbial fertilizers. Contemporary Agriculture, 67, 40 44. doi: 10.2478/contagri-2018-0006 https: / content.sciendo.com/view/journals/contagri/67/1/articlep40.xml

Betencourt, E., Duputel, M., Colomb, B., Desclaux, D., Hinsinger, P. (2012). Intercropping promotes the ability of durum wheat and chickpea to increase thizosphere phosphorus availability in a low $\mathrm{P}$ soil. Soil Biol Biochem, 46, 181-190. doi: 10.1016/j.soilbio.2011.11.015 https://www.sciencedirect.com/science/article/abs/pii/ S003807171100407X

van Bruggen, A.H.C., Gamliel, A., Finckh, M.R. (2016). Plant disease management in organic farming systems. Pest Mamag Siz, 72, 30-44 doi: 10.1002/ps.4145 https://onlinelibrary.wiley.com/doi/ abs $/ \mathbf{1 0 . 1 0 0 2 / p s . 4 1 4 5}$

Carlos, B.V.J., Mendez-Valencia, D., Ramos-Garcia, A., MartinezRodriguez, O.K., Morales-López, G-, Salas-Galvan, M.E., TorresArteaga, I.C. (2018). Development of sustainable agriculture through protocols of organic fertilization and its comparison with traditional method applied to the cultivation of radish (Raphams satinus). In W/ Leal Filho, R Noyola-Cherpitel, P Medellin-Milán, V Ruiz Vargas, eds, Sustainable Development Research ana Practice in Mexico and Selectea Latin American Countries. Springer International Publishing, Cham, Switzerland, pp 439-454. doi: 10.1007/978-3-319 -70560-6_28 https://link.springer.com/chapter/10.1007/978-3-319 -70560-6_28

Chhikara, N., Kushwaha, K., Sharma, P., Gat, Y., Panghal, A. (2019). Bioactive compounds of beetroot and utilization in food processing industry: A critical review. Foo Chem, 272, 192-200. doi: 10.1016/ i.foodchem.2018.08.022 https://www.sciencedirect.com/science/ article/abs/pii/S0308814618314146

Dinić, Z., Ugrinović, M., Bosnić, P., Mijatović, M., Zdravković, J., Miladinović, M., Jošić, D. (2014). Solubilization of inorganic phosphate by endophytic Fseuiomonas sp. from French bean nodules. Ratar Forrt , 51, 100-105. doi: 10.5937/ratpov51-6222 https://scindeks-clanci.ceon.rs/data/pdf/1821-3944/2014/182139441402100D.pdf

Dubrovsky, M., Hayes, M., Duce, P., Trnka, M., Svoboda, M., Zara, P. (2013). Multi-GCM projections of future drought and climatevariability indicators for the Mediterranean region. Regional Envi-ronmental Change 14, 1907-1919. doi: 10.1111/bor.12320 https://ezproxy.nb.rs:2069/doi/epdf/10.1111/bor.12320

EUROSTAT (2019). Available via https://appsso.eurostat.ec.europa.eu/ nui/submit View TableAction.do Accessed 2 March 2020

Garibaldi, L.A., Gemmil-Herren, B., D'Annolfo, R., Graeub, B.E., Cunningtham, S.A, Breeze, T.D. (2017). Farming approaches for greater biodiversity, livelihoods, and food security. Irenas Ecol Evol, 32, 68-80. doi: 10.1016/j.tree.2016.10.001 https:// www.sciencedirect.com/science/article/abs/pii/ S0169534716301768

Gosal, S.K, Kalia, A., Uppal, S.K., Kumar, R, Walia, S.S., Singh, K, Singh, H (2012). Assessing the benefits of Azotobacter bacterization in sugarcane: A field Appraisal. Sugar Tech, 14, 61-67. doi: 10.1007/s12355-011-0131-z https://link.springer.com/ article/ $10.1007 / \mathrm{s} 12355-011-0131-\mathrm{z}$

Hayat, R, Ali, S., Amara, U., Khalid, R, Ahmed, I. (2010). Soil beneficial bacteria and their role in plant growth promotion: a review. Am Microbiol, 60, 579-598. doi: 10.1007/s13213-010-0117-1 https:// link.springer.com/article/10.1007/s13213-010-0117-1

Hu, T., Sorensen, P., Olesen, J.E. (2018). Soil carbon varies between different organic and conventional management schemes in arable agriculture. Eur / Agron , 94, 79-88. doi: 10.1016/j.eja.2018.01.010 https://www.sciencedirect.com/science/article/abs/pii/ S1161030118300108
IFOAM (2019). Principles of organic agriculture. Available via https:// www.ifoam-eu.org/en/what-we-do/farm-food-environment Accessed 13 January 2020

Kawasaki, K. (2019). Two harvests are better than one: double croppingas a strategy for climate change adaptation. Amer 7 Agr Econ, 101, 172-192. doi: 10.1093/ajae/aay051 https:/acadenic.oup.com/ ajae/article-abstract/ 101/1/172/5060834

Lee, K.S., Choe, Y.C., Park, S.H. (2015). Measuring the environmental effects of organic farming: A meta-analysis of structural variables in empirical research. ] Emivon Manage, 162, 263-274. doi: 10.1016/ j.jenvman.2015.07.021 https://www.sciencedirect.com/science/ article/pii/S0301479715301663

Lorenz, K., Lal, L. (2016). Chapter three - Environmental impact of organic agriculture. Adv Agron, 139, 99-152. doi: 10.1016/ bs.agron.2016.05.003 https://www.sciencedirect.com/science/ article/pii/S006521131630061X

Maroušek, J., Kolár, L., Vochozka, M., Stehel, V., Maroušková, A. (2017). Novel method for cultivating beetroot reduces nitrate content. ] Clean Proả, 168, 60 62. doi: 10.1016/j.jclepro.2017.08.233 https:// www.sciencedirect.com/science/article/pii/S0959652617319340

MAFWM - Ministry of Agriculture, Forestry and Water Economy (2010). Law on Organic Production. Official Gazette of the Republic of Serbia 30/2010. Available via http:// www.dnrl.minpolj.gov.rs/o_nama/organska/organska.html Accessed 11 January 2020

MAFWM - Ministry of Agriculture, Forestry and Water Economy (2011). Rules on Control and Certification in Organic Fanning and Ornami Production Methods. Official Gazette of the Republic of Serbia 48/2011. Available via http://www.dnrl.minpolj.gov.rs/o_nama/ organska/organska.html Accessed 30 January 2020

MAFWM - Ministry of Agriculture, Forestry and Water Economy (2019). National List of Certified Plant V avieties of the Republic of Serbia. Available via http://www.sorte.minpoligov.rs/sites/default/files/ rsprilogom_3.pdf Accessed 12 January 2020

Miskoska - Milevska, E., Najdenovska, O., Popovski, Z., Dimovska, D. (2018). The influence of the microbiological fertilizer - Slavol on cauliflower growth. Roman Biotech Lett, 2 (2). pp. 13511-13516. ISSN 1224 - 5984 http://eprints.ugd.edu.mk/21862/1/Impakt $\%$ 20trud.pdf

Nunes, R.L.C., Neto, F.B., de Lima, J.S.S., Júnior, A.P.B., Chaves, A.P., da Silva, J.N. (2018). Agro-economic responsiveness of radish associations with cowpea in the presence of different amounts of Calotropis procera, spatial arrangements and agricultural crops. Ciênc Agrotec, 42, 350-363. doi: 10.1590/1413-70542018424010318 https://www.scielo.br/pdf/cagro/v42n4/1981-1829-cagro-42-04350.pdf

Pinheiro, M.S., Pereira, J.S., Coutinho, C.R., Filgueiras, R.M.C., Guimarães, M.A., Mesquita, R.O. (2019). Intercropping of collard green and radish 'Cometo': spatial arrangement and growing efficiency. Rev Ceres Viçosa, 66, 243-248. doi: 10.1590/0034 $737 \times 201966040001$ https://www.scielo.br/pdf/rceres/ v66n4/0034-737X-rceres-66-04-243.pdf

de Ponti, T., Rijk, B., van Ittersum, M.K (2012). The crop yield gap between organic and conventional agriculture. Agric Syst, 108, 1-9. doi: $10.1016 /$ j.agsy.2011.12.004 https://www.sciencedirect.com/ science/article/pii/S0308521X1100182X

Republic Hydrometeorological Service of Serbia (2019). Available via http://www.hidmet.gov.rs/ Accessed 13 January 2019

Sandler, L.N., Nelson, K.A., Dudenhoeffer, C.J., Miles, R.J., Motavalli, P.P. (2015). Effect of radish overseeded planting date on interseeded soybean and corn yield. Crop, Forage and Turgrass Management, 1, 1-10. doi: 10.2134/cftm2015.0119 https:// acsess.onlinelibrary.wiley.com/doi/abs $/ 10.2134 / \mathrm{cftm} 2015.0119$

Sripontan, Y., Tan, C.W., Hung, M.H., Young, C.C., Hwang, S.Y. (2014). Effects of plant-growth-promoting microorganisms and fertilizers on growth of cabbage and tomato and Spodoptera litura performance. I Asia-Pac Entomol, 17, 587-593. doi: 10.1016/ 
j.aspen.2014.05.007 https://www.sciencedirect.com/science/article/ abs/pii/S1226861514000673

Stamenković, S., Beškoski, V., Karabegović, I., Lazić, M., Nikolić, N. (2018). Microbial fertilizers: A comprehensive review of current findings and future perspectives. Span J Agric Res, 16, e09R01. doi: 10.5424/sjar/2018161-12117 http://cherry.chem.bg.ac.rs/ bitstream/handle/ $123456789 / 2136 / 2134 . p d f$ ? sequence $=1 \&$ is Allowed $=y$

Ugrinovic, M., Mijatovic, M., Zdravkovic, J., Girek, Z., Kuzmanovic, D., Rasulic, N., Josic, D. (2014). Intercropped red beet and radish with green bean affected microbial communities and nodulation by indigenous rhizobia. Agr Food Siz, 23, 173-185. doi: 10.23986/ afsci. 41385 https://journal.fi/afs/article/view/41385/13852

Vandermeer, J.H. (1989). The ecology of intercropping. Cambridge University Press, Cambridge, UK, pp 1-237. doi: 10.1017 CBO9780511623523
Yildirim, E., Guvenc, I. (2005). Intercropping based on cauliflower: more productive, profitable and highly sustainable. Eur J Agron, 22, 11-18. doi: 10.1016/j.eja.2003.11.003 https:// www.sciencedirect.com/science/article/abs/pii/ S11610301030015404

Zandi, P., Basu, S.K. (2016). Role of plant growth-promoting rhizobacteria (PGPR) as biofertilizers in stabilizing agricultural ecosystems. In D Nandwani, ed, Organic farming for sustainable agriculture: Sustainable Development and Biodiversity, Vol 9. Springer International Publishing, Cham, Switzerland, pp 71-87. doi: 10.1007/978-3-319-26803-3_3 https://link.springer.com/ chapter/10.1007/978-3-319-26803-3_3

\section{Prinosi korena organske cvekle i rotkve gajenih u čistom i združenom usevu}

\section{Milan Ugrinović* · Bogoljub Zečević · Zdenka Girek · Suzana Pavlović · Ivan Krga · Jelena Damnjanović - Milka Brdar Jokanović}

Sažetak: Uprkos brojnim pozitivnim efektima na životnu sredinu, povećanoj tražnji, intenzivnim istraživanjima i adekvatnoj pažnji javnosti, usevi uzgajani po principima organske proizvodnje i dalje zauzimaju prilično male površine. Certifikovani proizvođači teško se odlučuju na proširenje proizvodnje certifikovanog organskog povrća. Jedan od razloga je nedovoljno razvijena tehnologija gajenja razlicitih vrsta povrća u skladu sa Zakonom i propisima o organskoj proizvodnji. Združivanje, gajenje postrnih useva i primena mikrobioloških đubriva smatraju se najkorisnijim tehnikama za povećanje prinosa u održivim sistemima zemljoradnje. Cilj ovog istraživanja bio je da se utvrdi mogućnost povećanja prinosa korena cvekle i rotkve gajenih postrno u združenom usevu po metodama organske proizvodnje. Praćeni su efekti združivanja i primene mikrobioloških đubriva na masu korena. Združivanje crekle i rotkve sa boranijom obavljeno je po metodi zamenjujućih serija. U ogledu su korišćena dva mikrobiološka đubriva od kojih jedno sadrži odabrane sojeve Bacillus megaterium, B. Licheniformis, B. suptilis, Ažotobacter chrocoocum, $A$. vinelandi i Derxia sp. (M1), a drugo: Bacillus subtilis, Azotobacter sp., Penicillium oxalicum i Fusarium sp. (M2). Združivanje i mikrobiološka đubriva doprineli su povećanju mase korena. Najveća masa korena zabeležena je u združenom usevu cvekle kod tretmana mikrobiološkim đubrivom M1 $(151,8 \mathrm{~g})$ i u združenom usevu rotkve kod tretmana mikrobiološkim đubrivom M2 (351,0g), što je bilo za $23,5 \%$ i $15,5 \%$ više u poređenju sa čistim usevima na tretmanima bez dubrenja. Dobijeni rezultati pokazuju da su uporedo primenjeno združivanje i odgovarajuća mikrobiološka đubriva delotvorna strategija za postizanje većih prinosa cvekle i rotkve u organskom sistemu gajenja. Ključne reči: Beta vulgaris L. var. rubra, organska proizvodnja, združivanje, mikrobiološka đubriva, Raphanus sativus L.

This article is distributed under the terms of the Creative Commons Attribution 4.0 International License (http://creativecommons.org/licenses/bv/4.0 which permits unrestricted use, distribution and reproduction in any medium, provided you give appropriate credit to the original author(s) and the source, provide a link to the Creative Commons license, and indicate if changes were made. 